\title{
Evaluation of lifestyle and quality of life in the elderly: a literature review
}

Luana Karoline Ferreira'

Juliana Fernandes Filgueiras Meireles² Maria Elisa Caputo Ferreira ${ }^{3}$

\section{Abstract}

Objective: to analyze Brazilian and non-Brazilian scientific production that considers the relationship between the lifestyle and quality of life of the elderly. Method: an integrative review of literature was performed in the Scopus, PubMed, Virtual Health Library and PsycINFO databases. Four cross-searches were adopted: the English synonyms of the word "elderly" ("Aged", "Aging", "Old age" and "Elderly") with the terms "Quality of life" and "Lifestyle". Results: after the adoption of the inclusion and exclusion criteria, 21 articles were analyzed. Physical activity, diet, body composition, alcohol intake, smoking and social relations were the main components of lifestyle investigated. The studies show that these factors influence the perception of the quality of life of the elderly. In addition to these factors, sociodemographic characteristics, functional capacity, sleep quality and comorbidities are also factors that influence the quality of life of the elderly. Conclusion: interest in the relationship between the lifestyle and quality of life of the elderly has increased in recent years. It was observed that the lifestyle of the elderly has been investigated in several ways, however no qualitative studies were found using the search criteria adopted in this review. As future perspectives, it is hoped that tools for evaluating the lifestyle of the elderly will be developed and qualitative investigations will be carried out in order to obtain a deeper understanding of the specificities that exist in the relationship between the lifestyle and levels of quality of life in old age.

\footnotetext{
1 Universidade Federal de Juiz de Fora, Programa de pós-graduação em Psicologia. Juiz de Fora, Minas Gerais, Brasil.

2 Faculdade do Sudeste Mineiro (Facum/FJF). Juiz de Fora, Minas Gerais, Brasil.

3 Universidade Federal de Juiz de Fora, Faculdade de Educação Física e Desportos,. Juiz de Fora, Minas Gerais, Brasil.
}

Keywords: Health of the Elderly. Life Style. Quality of Life. Review. 


\section{INTRODUCTION}

The world is undergoing a process of sociodemographic transition, and the fastest growing age group is those aged over $60^{1}$. Global aging represents a major challenge as it can even influence the development of countries, bringing about economic and social change ${ }^{2}$. Increases in life expectancy also have consequences for public health. The conditions in which a population ages are a growing concern due to the increase in the number of recurrent diseases among the elderly ${ }^{3}$. From this perspective, there may be changes in the health and quality of life of the elderly population, making it important to understand the risk and protective factors that influence these components ${ }^{4-6}$.

The World Health Organization Quality of Life (WHOQOL) - the research into quality of life group of the World Health Organization ${ }^{7}$ - defines quality of life as a comprehensive concept that involves not only physical health but also psychological state, level of independence, social relationships, personal beliefs and other characteristics involved in the environment of the individual, including a system of values involving goals, expectations, standards and worries ${ }^{7}$. Investigating the factors that can influence the perception of quality of life of an individual such as the state of health and socioeconomic factors is of great importance. The components of lifestyle have also been investigated as one of these factors.

Lifestyle is characterized as a set of habits, choices and customs experienced by individuals throughout life. Among these habits and choices are the ingestion of alcoholic beverages, smoking, diet, physical exercise and others ${ }^{8}$. The absence of smoking, low alcohol consumption and the practice of physical exercise are associated with a better Quality of Life $^{4,9,10}$. There is also considerable scientific interest in how other components such as diet and social aspects influence the individual's perception of their quality of life $e^{4,9,11-17}$.

Thus, in view of the possible influence of lifestyle behaviors on quality of life, the objective of this study was to analyze Brazilian and nonBrazilian scientific production that analyzes the relationship between the lifestyle and quality of life of the elderly.

\section{METHOD}

A systematic literature review was carried out in the Scopus, PubMed, Virtual Health Library (VHL) and PsycINFO databases from June 5 to June 30, 2017. Four cross searches were used using the English synonyms of the word "idoso" ("Aged", "Aging", "Old age" and "Elderly"), commonly associated with the theme of the study, with the terms "Quality of life" and "Lifestyle" which are descriptors indexed to the Health Science Descriptors (DeCS) system. We chose to use the terms in English since the search using the descriptors in Portuguese presented a limited number of findings. Due to the large number of works found with the search in English, it was decided to delimit by date, in order to identify the most updated bibliography on the subject. Thus, articles published between January 1, 2012 and January 7, 2018 were included.

The Scopus database was chosen due to its multidisciplinary nature. On this basis, the "all fields" option was selected and, in the "document type" section, it was decided to include only articles ("article"). The PubMed database was used as it is considered one of the most relevant sources of health research today. In this, the following filters in the advanced search were selected: "Title/abstract" and, in "article type", only "journal article". The VHL database was chosen because of its coverage throughout Brazil and the search was carried out using the "Limit" filter, selecting the "human" option so that the search was performed only in studies that used human samples. Finally, as the construct quality of life is widely studied in the field of psychology, PsyINFO, which is considered one of the most important databases in this area was chosen, and an advanced search using the "any field" option was used.

After insertion of the articles that fulfilled the inclusion criteria described above, four documents were created for each database from the searches performed - "Aged" and "Quality of life" and "Lifestyle" (document 1), "Aging" and "Quality of life" and "Lifestyle" (document 2) "Old age" and "Quality of life" and "Lifestyle" (document 3), "Elderly" and "Quality of life" and "Lifestyle" (document 4) - containing the titles of all the references found. As for the exclusion criteria, articles that were duplicated in the databases were identified and deleted. Thus, the documents were compared until each article appeared only once. 
In the second stage, the titles and/or abstracts were read. At this stage, documents such as chapters of books, commentaries and dissertations were excluded so that only articles were considered. Those that did not have the evaluation of quality of life and/or lifestyle (Stage 3) as their main objective were excluded. We also excluded those where the abstracts not available (Step 4), those that did not use empirical methodology (Step 5) and those that included individuals under 60 in their sample (Step 6).

In the last step, studies that were not fully in Portuguese, English or Spanish (Stage 8) were excluded. Finally, the articles included were searched in full. In addition to the databases themselves, the Capes Periodical Portal was used as a resource for access to the full texts. Those articles that were not free access were also excluded.

After the inclusion and exclusion criteria were applied, a thorough reading of the articles was carried out. In the analysis of the data, we sought to extract the following information from included studies:
1) authorship and year; 2) country of publication; 3) methodology used; 4) characteristic of the sample; 5) instruments used to assess the quality of life; 5) lifestyle components analyzed. Finally, the analysis and interpretation of the data of each study included in this review was performed. The findings that were found in these studies were organized and discussed considering the three main axes: quality of life of the elderly, lifestyle components of the elderly, lifestyle and quality of life of the elderly.

\section{RESULTS}

In total 8516 documents on the lifestyle and quality of life of the elderly were found based on the criteria used in the searches. Table 1 shows the number of documents found in each of the databases by combination of keywords.

After applying the exclusion criteria adopted, a total of 24 articles were submitted for final analysis. Table 2 and Figure 1 present in detail the articles excluded according to each pre-established criterion.

Table 1. Number of publications found in each database. Juiz de Fora, Minas Gerais, 2018.

\begin{tabular}{llllll}
\hline Combinations & Scopus & Pubmed & BVS & PsicINFO & Total \\
\hline "aged" AND "quality of life" AND "lifestyle" & 2132 & 427 & 1560 & 460 & 4579 \\
"aging" AND "quality of life" AND "lifestyle" & 687 & 121 & 235 & 134 & 1177 \\
"old age” AND "quality of life" AND "lifestyle" & 483 & 40 & 426 & 14 & 963 \\
"elderly" AND "quality of life" AND "lifestyle" & 515 & 273 & 964 & 45 & 1797 \\
\hline Total & 3817 & 861 & 3185 & 653 & 8516 \\
\hline
\end{tabular}

Table 2. Number of publications excluded based on criteria from databases. Juiz de Fora, Minas Gerais, 2018.

\begin{tabular}{lllll}
\hline & Scopus & Pubmed & BVS & PsicINFO \\
\hline Initial total in each database & 3817 & 861 & 3185 & 653 \\
Exclusion Criteria & & & & 411 \\
Articles in duplicate & 2998 & 750 & 1485 & 42 \\
Other types of documents & 0 & 0 & 0 & 168 \\
Articles without instruments of evaluation of Quality of Life & 705 & 110 & 2 & 0 \\
Abstracts not available & 0 & 0 & 2 & 0 \\
Non-empirical studies & 0 & 0 & 49 & 30 \\
Sample less than 60 years old & 98 & 0 & 141 & 2 \\
Articles without evaluation of any component of Lifestyle & 9 & 0 & 0 & 0 \\
Articles in other languages & 1 & 0 & 1 & 0 \\
Articles not available in entirety & 0 & 0 & 17 & 0 \\
\hline Total for analysis & 6 & 1 & & 348 \\
\hline
\end{tabular}




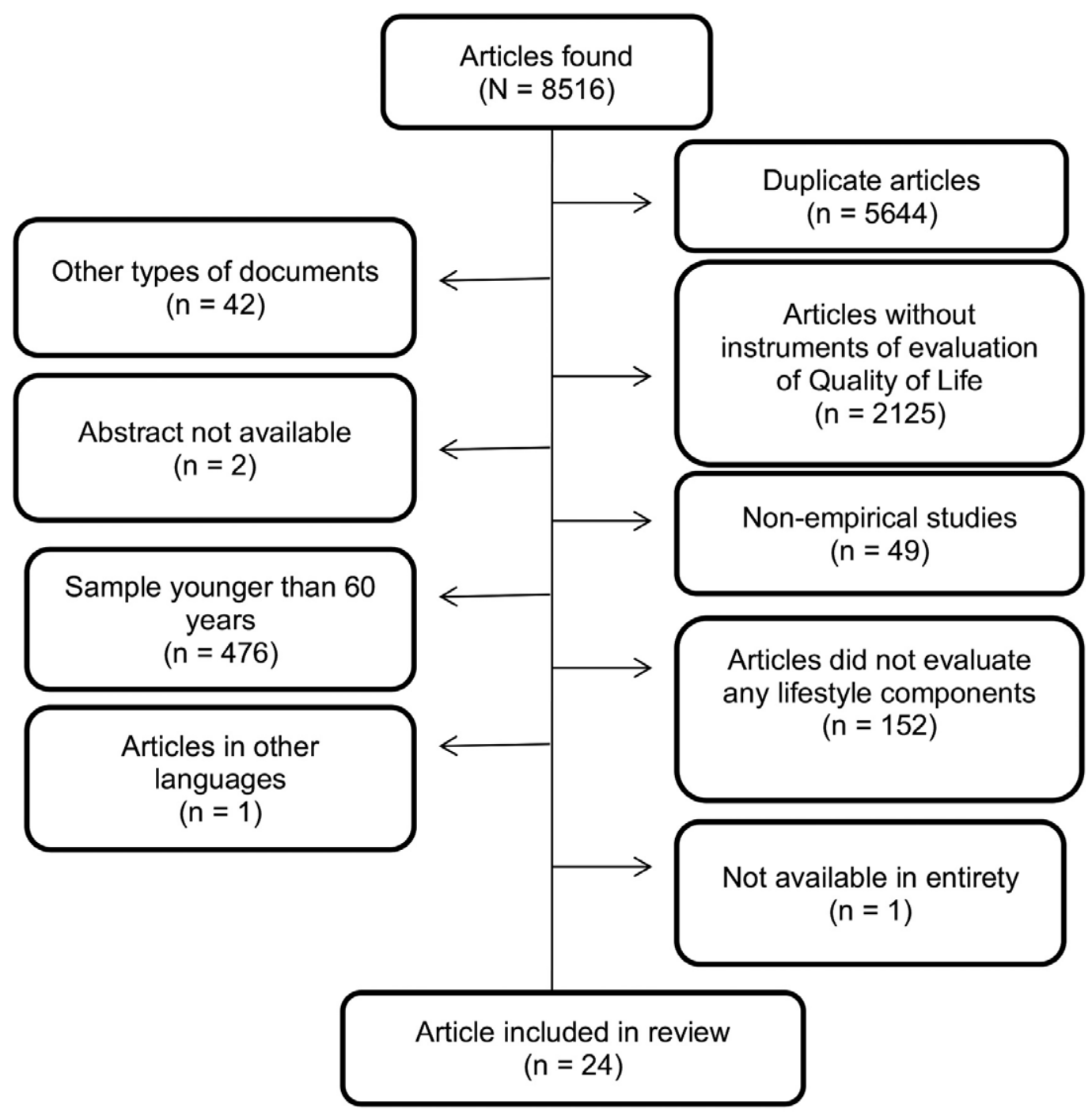

Figure 1. Number of excluded publications based on total number of articles. Juiz de Fora, Minas Gerais, 2018.

It is important to stress that while the terms "aged", "aging", "old age" and "elderly" were used during the search, the samples of many of the articles found were not exclusively of elderly persons. As one of the established objectives of this review was to identify the current panorama of these studies specifically among the elderly public, only articles with samples of individuals over 60 years were considered. Another fact is that, despite using the term "quality of life" or "lifestyle" in the title, abstract or keywords, many investigations did not attempt to evaluate the relationship between these constructs and were therefore deleted. After the selection and analysis of the articles covered in this review $(\mathrm{N}=21)$ the authors, year and country of publication, method used, sample characteristics and lifestyle behaviors of each study were assessed. Table 1 presents this information in detail.. 
Chart 1. Studies on lifestyle and quality of life of the elderly. Juiz de Fora, Minas Gerais, 2018.

\begin{tabular}{|c|c|c|c|}
\hline Reference (year) & Country and sample & Method & $\begin{array}{l}\text { Lifestyle Components evaluated } \\
\text { in study }\end{array}$ \\
\hline $\begin{array}{l}\text { Zaragoza-martí et } \\
\text { al. }{ }^{18} \text { (2018) }\end{array}$ & $\begin{array}{l}\text { Spain } \\
351 \text { elderly men and women aged over } 60\end{array}$ & $\begin{array}{l}\text { Quantitative } \\
\text { Cross- } \\
\text { sectional }\end{array}$ & $\begin{array}{l}\text { Smoking } \\
\text { Alcohol } \\
\text { Body composition } \\
\text { Physical activity } \\
\text { Diet }\end{array}$ \\
\hline $\begin{array}{l}\text { Bayán-Bravo et } \\
\text { al. }{ }^{19}(2017)\end{array}$ & $\begin{array}{l}\text { Spain } \\
1,323 \text { elderly men and women aged over } 60\end{array}$ & $\begin{array}{l}\text { Quantitative } \\
\text { Cross- } \\
\text { sectional }\end{array}$ & $\begin{array}{l}\text { Smoking } \\
\text { Alcohol } \\
\text { Physical activity } \\
\text { Diet } \\
\text { Body composition }\end{array}$ \\
\hline $\begin{array}{l}\text { Máchon et al. }{ }^{20} \\
(2017)\end{array}$ & $\begin{array}{l}\text { Spain } \\
800 \text { elderly persons aged over } 65\end{array}$ & $\begin{array}{l}\text { Quantitative } \\
\text { Cross- } \\
\text { sectional }\end{array}$ & $\begin{array}{l}\text { Smoking } \\
\text { Social conviviality } \\
\text { Physical activity } \\
\text { Nutritional risk }\end{array}$ \\
\hline $\begin{array}{l}\text { Gouveia et al. }{ }^{20} \\
(2017)\end{array}$ & $\begin{array}{l}\text { Portugal } \\
802 \text { elderly men and women, distributed in } \\
\text { two groups ( } 60-69 \text { and } 70-79 \text { years) }\end{array}$ & $\begin{array}{l}\text { Quantitative } \\
\text { Cross- } \\
\text { sectional }\end{array}$ & $\begin{array}{l}\text { Physical activity } \\
\text { Body composition }\end{array}$ \\
\hline $\begin{array}{l}\text { Moreno-Vencino } \\
\text { et al. }{ }^{22}(2017)\end{array}$ & $\begin{array}{l}\text { Spain } \\
463 \text { elderly women aged between } 66 \text { and } 91 \\
\text { years }\end{array}$ & $\begin{array}{l}\text { Quantitative } \\
\text { Cross- } \\
\text { sectional }\end{array}$ & Body composition \\
\hline $\begin{array}{l}\text { Camelo et al. }{ }^{23} \\
(2016)\end{array}$ & $\begin{array}{l}\text { Brazil } \\
366 \text { elderly men and women aged between } 60 \\
\text { and } 94 \text { years }\end{array}$ & $\begin{array}{l}\text { Quantitative } \\
\text { Cross- } \\
\text { sectional }\end{array}$ & $\begin{array}{l}\text { Social aspects Diet } \\
\text { Level of physical activity } \\
\text { Smoking }\end{array}$ \\
\hline $\begin{array}{l}\text { Cerin et al. }{ }^{12} \\
(2016)\end{array}$ & $\begin{array}{l}\text { China } \\
900 \text { elderly men and women aged over } 65 \text { years }\end{array}$ & $\begin{array}{l}\text { Quantitative } \\
\text { Longitudinal }\end{array}$ & $\begin{array}{l}\text { Physical activity } \\
\text { Neighborhood environment } \\
\text { Social relations }\end{array}$ \\
\hline $\begin{array}{l}\text { Chatiziralli et al. }{ }^{9} \\
(2016)\end{array}$ & $\begin{array}{l}\text { Greece } \\
114 \text { elderly men and women aged between } \\
65 \text { and } 75 \text { years diagnosed with muscular } \\
\text { degeneration }\end{array}$ & $\begin{array}{l}\text { Quantitative } \\
\text { Cross- } \\
\text { sectional }\end{array}$ & $\begin{array}{l}\text { Smoking } \\
\text { Alcohol consumption } \\
\text { Physical exercises } \\
\text { Walking }\end{array}$ \\
\hline $\begin{array}{l}\text { Dohrn et al. }{ }^{24} \\
(2016)\end{array}$ & $\begin{array}{l}\text { Sweden } \\
96 \text { elderly men and women aged between } 66 \\
\text { and } 86 \text { years with osteoporosis }\end{array}$ & $\begin{array}{l}\text { Quantitative } \\
\text { Cross- } \\
\text { sectional }\end{array}$ & $\begin{array}{l}\text { Physical activity } \\
\text { Gait speed } \\
\text { Duration of sedentarism }\end{array}$ \\
\hline $\begin{array}{l}\text { Marques et al. }{ }^{13} \\
(2016)\end{array}$ & $\begin{array}{l}\text { Brazil } \\
1131 \text { elderly men and women aged over } 60\end{array}$ & $\begin{array}{l}\text { Quantitative } \\
\text { Cross- } \\
\text { sectional }\end{array}$ & $\begin{array}{l}\text { Employment } \\
\text { Internet use } \\
\text { Physical activity } \\
\text { Religiosity } \\
\text { Participation in religious } \\
\text { groups or lifestyle }\end{array}$ \\
\hline $\begin{array}{l}\text { Naughton et al. }{ }^{4} \\
(2016)\end{array}$ & $\begin{array}{l}\text { USA } \\
26299 \text { women aged } 80 \text { or over }\end{array}$ & $\begin{array}{l}\text { Quantitative } \\
\text { Longitudinal }\end{array}$ & $\begin{array}{l}\text { Physical activity } \\
\text { Body composition; } \\
\text { Smoking }\end{array}$ \\
\hline
\end{tabular}


Continuation of Chart 1

\begin{tabular}{|c|c|c|c|}
\hline Reference (year) & Country and sample & Method & $\begin{array}{l}\text { Lifestyle Components evaluated } \\
\text { in study }\end{array}$ \\
\hline Pan et al. ${ }^{11}$ (2016) & $\begin{array}{l}\text { China } \\
5557 \text { elderly persons aged over } 60\end{array}$ & $\begin{array}{l}\text { Quantitative } \\
\text { Cross- } \\
\text { sectional }\end{array}$ & $\begin{array}{l}\text { Tea-drinking } \\
\text { Diet } \\
\text { Smoking } \\
\text { Alcohol consumption } \\
\text { Open air activities }\end{array}$ \\
\hline $\begin{array}{l}\text { Aguero e Leiva et } \\
\text { al. }^{14}(2015)\end{array}$ & $\begin{array}{l}\text { Chile } \\
271 \text { elderly men and women aged between } 80 \\
\text { and } 90\end{array}$ & $\begin{array}{l}\text { Quantitative } \\
\text { Cross- } \\
\text { sectional }\end{array}$ & Dietary habits \\
\hline $\begin{array}{l}\text { Blair et al. }{ }^{25} \\
(2015)\end{array}$ & $\begin{array}{l}\text { USA } \\
1776 \text { elderly women who had survived cancer } \\
\text { and } 12599 \text { elderly women without cancer aged } \\
\text { between } 73 \text { and } 88 \text { years }\end{array}$ & $\begin{array}{l}\text { Quantitative } \\
\text { Longitudinal }\end{array}$ & $\begin{array}{l}\text { Physical activity } \\
\text { Smoking } \\
\text { Dietary habits } \\
\text { Body composition }\end{array}$ \\
\hline $\begin{array}{l}\text { Harada et al. }{ }^{26} \\
(2015)\end{array}$ & $\begin{array}{l}\text { Japan } \\
1351 \text { elderly men and women aged between } 65 \\
\text { and } 74 \text { years }\end{array}$ & $\begin{array}{l}\text { Quantitative } \\
\text { Cross- } \\
\text { sectional }\end{array}$ & Physical activity \\
\hline $\begin{array}{l}\text { Meneguci et al. }{ }^{15} \\
(2015)\end{array}$ & $\begin{array}{l}\text { Brazil } \\
3206 \text { elderly men and women aged over } 60\end{array}$ & $\begin{array}{l}\text { Quantitative } \\
\text { Cross- } \\
\text { sectional }\end{array}$ & Time seated \\
\hline $\begin{array}{l}\text { Duran et al. } .^{27} \\
(2014)\end{array}$ & $\begin{array}{l}\text { Chile } \\
975 \text { elderly men and women aged over } 60\end{array}$ & $\begin{array}{l}\text { Quantitative } \\
\text { Cross- } \\
\text { sectional }\end{array}$ & Body composition \\
\hline $\begin{array}{l}\text { Freitas et al. }{ }^{28} \\
(2014)\end{array}$ & $\begin{array}{l}\text { Brazil } \\
60 \text { elderly men and women ( } 30 \text { physically active } \\
\text { and } 30 \text { physically inactive) aged over } 60\end{array}$ & $\begin{array}{l}\text { Quantitative } \\
\text { Cross- } \\
\text { sectional }\end{array}$ & Physical activity \\
\hline $\begin{array}{l}\text { Milla et al. } \\
(2014)\end{array}$ & $\begin{array}{l}\text { Chile } \\
1285 \text { elderly men and women aged over } 60\end{array}$ & $\begin{array}{l}\text { Quantitative } \\
\text { Cross- } \\
\text { sectional }\end{array}$ & $\begin{array}{l}\text { Eats breakfast } \\
\text { Body composition }\end{array}$ \\
\hline $\begin{array}{l}\text { Atkins et al. }{ }^{16} \\
(2013)\end{array}$ & $\begin{array}{l}\text { Australia } \\
626 \text { elderly men and women aged over } 60\end{array}$ & $\begin{array}{l}\text { Quantitative } \\
\text { Cross- } \\
\text { sectional }\end{array}$ & $\begin{array}{l}\text { Level of physical activity } \\
\text { Open air activities } \\
\text { Social relationship } \\
\text { Consumption of alcohol } \\
\text { Time seated }\end{array}$ \\
\hline Silva et al. ${ }^{29}(2012)$ & $\begin{array}{l}\text { Brazil } \\
50 \text { elderly men and women aged over } 60\end{array}$ & $\begin{array}{l}\text { Quantitative } \\
\text { Cross- } \\
\text { sectional }\end{array}$ & Level of physical activity \\
\hline $\begin{array}{l}\text { Footit and } \\
\text { Anderson }{ }^{30} \\
(2012)\end{array}$ & $\begin{array}{l}\text { Australia } \\
328 \text { elderly men and women aged over } 65\end{array}$ & $\begin{array}{l}\text { Quantitative } \\
\text { Cross- } \\
\text { sectional }\end{array}$ & $\begin{array}{l}\text { Diet; } \\
\text { Physical activity } \\
\text { Smoking } \\
\text { Alcohol consumption } \\
\text { Health Promotion }\end{array}$ \\
\hline $\begin{array}{l}\text { Guedes et al. }{ }^{31} \\
(2012)\end{array}$ & $\begin{array}{l}\text { Brazil } \\
1204 \text { elderly men and women aged over } 60\end{array}$ & $\begin{array}{l}\text { Quantitative } \\
\text { Cross- } \\
\text { sectional }\end{array}$ & Physical activity \\
\hline $\begin{array}{l}\text { Porto et al. }{ }^{32} \\
(2012)\end{array}$ & $\begin{array}{l}\text { Brazil } \\
199 \text { elderly men and women aged between } 60 \\
\text { and } 70 \text { years }\end{array}$ & $\begin{array}{l}\text { Quantitative } \\
\text { Cross- } \\
\text { sectional }\end{array}$ & Physical activity \\
\hline
\end{tabular}


Regarding the countries of origin of the studies, Brazil $(n=7)$ produced the most work on the subject, followed by Spain $(\mathrm{n}=4)$ and Chile $(\mathrm{n}=3)$. The most publications were published in 2016 ( $\mathrm{n}=$ 8), followed by 2012 and $2017(n=4)$. All the articles had a quantitative approach and only three employed the longitudinal method ${ }^{4,2,25}$.

\section{DISCUSSION}

With increased life expectancy it is important to understand the factors that influence the quality of life of the elderly, as well as the components of lifestyle that can impact it. The present study found that studies have been carried out on this subject in countries of Europe, North America, Asia, Oceania and Latin America, demonstrating the importance given to the topic in a global context. There is notable productivity in Latin America, mainly in Brazil and in Chile. This can possibly be explained by the speed of population aging in developing countries. In Brazil, for example, due to the fall in fertility rate and the reduction of mortality in all age groups, the population aged 60 and over has reached 19.6 million people, and will climb to 41.5 million by $2030^{33}$.

In addition, the majority of the studies were carried out with samples of people aged 60 and above, with no age limit, and the sample was not stratified in order to compare differences related to age group. In this sense, it is worth emphasizing the importance of further studies that evaluate lifestyle and quality of life in different phases of aging. This aspect is considered an important moderator if effective quality of life and lifestyle interventions are to be planned for each age group ${ }^{1}$. None of the articles included in this review adopted a qualitative approach, demonstrating the need for studies that explore this theme more deeply, in order to understand the specificities of lifestyle and quality of life present in the narrative of the elderly.

To better understand the issues related to the evaluation of the lifestyle and quality of life of the elderly, we chose to divide this review into three central themes that will be discussed below.
Quality of life of the elderly

Given the subjective and multidimensional nature of the concept of quality of life, the instruments used for its evaluation are divided into dimensions and describe the individual's perception of their quality of life. The most used instrument in studies that relate style and quality of life is the Medical Outcome Study 36- item Short Form (SF-36) 9,21,24,25,28,30, composed of 36 items divided into eight domains: functional capacity, physical aspects, pain, general health, vitality, social aspects, emotional aspects and mental health. The score of each domain can vary from 0 to 100 , with scores close to 0 representing a worse perception of quality of life while those close to 100 , a better perception of quality of life ${ }^{2.4}$. Instruments similar to the SF-36 are also used as quicker to apply alternatives, such as the Medical Outcomes Study 12-Item Short-Form Health Survey (SF-12) ${ }^{23}$ and Medical Outcomes Study Short Form 8-Item Health Survey $(\text { SF-8) })^{15}$.

According to the findings of this review, in addition to lifestyle, the factors that influence the quality of life of the elderly are: gender ${ }^{9,14,15,23}$, age $^{13,15,21,23}$, schooling ${ }^{4,13,15,23}$, ethnic group ${ }^{4,23}$, physical capacity ${ }^{4,10,15,21-24}$, diseases ${ }^{4,9,21,23,24}$ and income ${ }^{23}$. In the study by Camelo et al. ${ }^{23}$, women over 70 years of age and with less than four years of schooling had a worse health-related quality of life in the physical and mental domains of SF-12 than men. In the physical domain of this same instrument, black women with incomes less than four times the minimum salary also had a worse quality of life. In contrast, in a study of women over 80 years of age conducted by Naughton et al. ${ }^{4}$, those with a higher education level than high school and who were married had the best quality of life scores. This was also a finding in the study by Marques et al. ${ }^{13}$, in which elderly people aged between 60 and 69 years and with more than 12 years of schooling also had a better quality of life.

Good quality of sleep is also associated with better quality of life among the elderly. It is important to understand which lifestyle components can influence quality of sleep. In a study carried out by MorenoVencino et al. ${ }^{22}$, it was observed that central obesity 
is associated with poorer sleep quality in elderly women, which also had an influence on the poor quality of life of this public.

The functional capacity of the elderly has also been strongly related to a better perception of quality of life ${ }^{15,21-24}$, as functional limitations among the elderly interfere with their mobility, social conviviality and autonomy influencing the perception of Quality of Life of these individuals. A worse functional status was also associated with greater psychological distress and lower quality of life in a study by Atkins et al. ${ }^{16}$. These results demonstrate the importance of adopting behavior during life that maintains good functional capacity in old age.

Studies have also been conducted that investigate the influence of diseases on the quality of life of this public. Comorbidities are important factors that influence the perception of the quality of life of the elderly. There are indications that the higher the number of diseases, the worse the perception of quality of life $\mathrm{f}^{23,25}$. This is an important fact that reinforces the importance of disease prevention, especially chronic diseases, as these can disrupt or cause various complications for the health of the elderly, thus impairing their quality of life. According to these same studies, interventions that seek to improve the social support network and increase the level of physical activity of the elderly can improve the perception of their quality of life in cases where diseases are already installed ${ }^{23-25}$.

It is also possible to understand that social and economic indicators influence the evaluation of the quality of life of the elderly ${ }^{4,23,34}$. In the study by Andrade et al. ${ }^{34}$ single, divorced and widowed elderly persons had a lower average quality of life. Regarding ethnicity, in the study of Camelo et al. ${ }^{23}$, black women presented the lowest scores in the physical domain of the instrument that evaluated quality of life, the SF-12. These results corroborate the findings of Naughton et al. ${ }^{4}$,in which African-American women older than 80 years, also had the worst quality of life scores. Also in the study of Camelo et al. ${ }^{23}$, elderly persons with a family income below four times the minimum wage had the worst quality of life scores, demonstrating that income can also influence the evaluation of this construct.
Studies that demonstrate the influence of sociodemographic characteristics on the perception of the quality of life of this population are important, since these factors interfere in health status, social support network and access to health promotion programs, among others ${ }^{4,23,34}$. These investigations are also relevant, as they can support the elaboration of strategies to improve the living conditions of these people and, consequently, the perception of quality of life of this public ${ }^{34}$.

All the factors mentioned here influence the way of life of the elderly person, interfering with their autonomy, their capacity to take care of themselves and to relate to others with consequences for their physical and emotional health and, consequently, their quality of life.

\section{Lifestyle components of the elderly}

There are a number of instruments for evaluating the lifestyle of individuals or groups, such as the Fantastic Lifestyle index ${ }^{35}$, the Breslow's Life Style Index ${ }^{36}$ questionnaire and the Pentacle Social Welfare Foundation ${ }^{37}$. None of these instruments is specific to the evaluation of the lifestyle of the elderly, meaning in the great majority of studies this construct is evaluated through questionnaires developed by the researchers themselves $9,11,13,15,23,25,30$.

Some components are often analyzed in studies that address the issue. Factors such as smoking, alcohol consumption and family and social relationships have been considered, mostly by means of sociodemographic questionnaires, in order to characterize the sample $2,4,5,9,14,15,25$. This information becomes important as it directly affects the longevity and way of life of the elderly. Smoking and alcohol consumption are responsible for several diseases, including the occurrence of chronic diseases ${ }^{38-40}$. Social and family relationships have great importance for the emotional health of the elderly. The elderly person's life in the family, at work or in the community, increases their social support by dialoging directly with mental health and contributing to the Quality of Life of the elderly $y^{4,13,15,16,23,27-29}$. 
Physical activity in this age group has also been significantly investigated in this age group. Some studies have evaluated the levels of physical activity through the International Physical Activity Questionnaire (IPAQ) $)^{12,15,28,29,31,32}$. This questionnaire allows the weekly time spent in physical activities of moderate and vigorous intensity present in daily life through work, transportation, domestic tasks and leisure to be evaluated, and also the time spent in passive activities performed in the sitting position ${ }^{42}$. It is important to remember that the practice of physical activity in the elderly is an important factor for the improvement of functional capacity, integration in society and mental health ${ }^{4,9,13,43}$.

Body composition is also an important factor to be evaluated in this age group as body modifications occur in aging that lead to a greater accumulation of fat and reduction of lean mass, predisposing the individual to a series of chronic diseases ${ }^{44}$. In the articles included in this review, most of the studies used the Body Mass Index (BMI) as a physical evaluation method. While it is known that BMI is not a good predictor of body composition due to changes in body composition in aging such as fat gain, the reduction of height and water levels, it is used to its ease of measurement and low $\operatorname{cost}^{45,46}$.

Diet was also identified as a component of the lifestyle of the elderly ${ }^{2,25,27,30}$. As it is known that a suitable diet is an important protector of chronic diseases, it becomes an important aspect for the health of the elderly. It is also necessary to take into account nutritional specificities during aging and the psychosocial aspects that can interact with food in this phase of life ${ }^{47}$.

\section{Lifestyle and quality of life of the elderly}

From the results of the articles included in this review, it is understood that the set of choices and habits of an individual, known as lifestyle, can influence the quality of life of the elderly, both positively and negatively. The main components addressed in the studies with the elderly were: physical activity, diet, body composition, alcohol intake, smoking and social relations.
Data related to physical activity were widely addressed in literature and were positively related to quality of life $5,9,13,15,21,22,24,25,28,29$. A longitudinal study conducted between 1986 and 2004 with two groups of women, one cancer survivors and the other free from the disease, found that both groups presented a worse quality of life when the participants were physically inactive $e^{25}$.

Physical activity can also influence quality of life as it interacts with other lifestyle components. Research conducted by Meneguci et al. ${ }^{15}$ shows that elderly people who spent more time sitting, as well as having lower scores in the physical domains of the instrument of quality of life used, tended to have less social participation, influencing the overall scores of the instrument.

A similar result was also found in the study by Freitas et al. ${ }^{28}$, in which active and inactive elderly women were analyzed, and the former had higher scores in the psychological domains of quality of life. Social interaction has been shown to be an important component that influences the quality of life of the elderly. Dissatisfaction with social relationships was associated with low scores in the mental health field of the SF-12 in a study by Camelo et al. In another study conducted by Marques et al. ${ }^{13}$, participation in religious groups, use of the Internet, and changes in social relations were associated with better quality of life.

Body composition is also related to quality of life in a number of studies ${ }^{4,15,19,21,22,27}$. In the study by Gouveia et al. ${ }^{21}$, the BMI results of the sample had a negative correlation with quality of life related to the health of the elderly. It is important to note that this factor is a consequence of other lifestyle components such as exercise and eating and also dialogues with other factors such as sleep quality ${ }^{22,27}$, or in other words, as it influences quality of sleep, this factor also influences the quality of life of the elderly.

Body composition and alcohol consumption and smoking, besides being negatively related to quality of life, can also cause other factors such as comorbidities resulting in a worse quality of life. As the study by Naughton et al. ${ }^{4}$ and Atkins et al. ${ }^{16}$, neither smoking nor alcohol were independent predictors of quality of life. 
Food also appears to be related to quality of life. The lower intake of vitamins and minerals, especially in women, was associated with greater daytime sleepiness and, consequently, a moderate perception of Quality of Life ${ }^{14}$. In a study developed by Pan et al. ${ }^{2}$, the main relationship analyzed was on the influence of tea consumption on quality of life, which presented a positive correlation. However, lifestylerelated data such as smoking, alcohol consumption, food and outdoor activities were collected, thus raising the hypothesis that lifestyle variables may be related to the results found in the study, that is, a better quality of life would not be directly related to tea consumption, but rather to a series of variables related to lifestyle.

In another study by Milla et al. ${ }^{21}$, which analyzed the influence of eating breakfast on quality of life, it was concluded that breakfast affected the nutrition domain of the instrument of quality of life used, thus affecting the overall quality of life score. The octogenarian sample of Aguero and Leiva et al. ${ }^{14}$ presented excess energy in their diet and insufficient amounts of vitamins and minerals, especially in women. This condition was associated with a moderate perception of quality of life.

It is important to emphasize that the present study has limitations in relation to the delimitation by date, including only articles of the last five years, and the non- inclusion of other databases, for example, those that include dissertations and theses. These delimitations were chosen as this theme presents a large number of published works, making it impossible to analyze all of them. However, the delimitation of dates allows the current panorama of research related to the style and quality of life of the elderly to be described.

\section{REFERENCES}

1. World Health Organization. Global health and aging. [place unknown]: National Institute of Health; 2011.

2. Pan WC, Ma Q, Sun HP, Xu Y, Luo N, Wang P. Tea consumption and health-related quality of life in older adults. J Nutr Health Aging. 2017;16(5):1-7.

\section{CONCLUSION}

Interest in the relationship between the style and quality of life of the elderly has increased in recent years. This review revealed that the lifestyle of the elderly has been researched in a variety of ways. Of the lifestyle components discussed in the literature, physical activity, body composition, alcohol and tobacco use and diet are the variables most related to the study of quality of life. However, it is important to emphasize that these factors are not always independent predictors of a good quality of life.

The relationship of psychosocial aspects (family support network and friends, stress management, participation in religious groups, among others) has also been investigated. It can be suggested that one significant difficulty of investigating components of lifestyle is the lack of tools that meet the specificities of the lifestyle of the elderly and that allow the evaluation of several components at the same time. In this sense, it is important to emphasize once again the evident interaction of lifestyle components in the improvement or deterioration of quality of life of the elderly.

It was observed that quality of life is the product of a series of behaviors adopted by the elderly, and is not influenced by only one component. In addition, social factors such as income, ethnicity, schooling and marital status can also interfere in the living conditions of this population and consequently in their perception of quality of life.

It is hoped that tools for evaluating the lifestyle of the elderly and qualitative investigations are developed in order to obtain a deeper understanding of the specificities that exist in the relationship between the lifestyle and levels of quality of life of this group in the different stages of aging.

3. World Health Organization. World report on aging and health. Luxemburgo: WHO; 2015.

4. Naughton MJ, Brunner RL, Hogan PE, Danhauer SC, Brenes GA, Bower DJ, et al. Global quality of life among WHI women aged 80 years and older. J Gerontol Ser A Biol Sci Med Sci. 2016;71(1):72-8. 
5. Footit J, Anderson D. Associations between perception of wellness and health-related quality of life, comorbidities, modifiable lifestyle factors and demographics in older Australians. Australas J Ageing. 2012;31(1):22-7.

6. Meurer ST, Antes, DL, Silva DAS, Benedetti TRD. Perfil do estilo de vida de idosos atletas. Est Interdiscipl Envelhec. 2013;18(2):401-9.

7. World Health Organization, Division of mental health and prevention of substance abuse. Measuring quality of life. Geneva: WHO; 1997.

8. World Health Organization, Centre for Health Development. A glossary of terms for community health care and services for older persons. Geneva: WHO; 2004. (Ageing and Health Technical Report, vol. 5).

9. Chatziralli I, Mitropoulos P, Parikakis E, Niakas D, Labiris G. Risk factors for poor quality of life among patients with age-related macular degeneration. Sem Ophthalmol. 2016:1-9.

10. Phillips SM, Stampfer MJ, Chan JM, Giovannucci EL, Kenfield SA. Physical activity, sedentary behavior, and health-related quality of life in prostate cancer survivors in the health professionals follow-up study. J Cancer Surviv. 2015;9(3):500-11.

11. Pan WC, Ma Q, Sun HP, Xu Y, Luo N, Wang P. Tea consumption and health-related quality of life in older adults. J Nutr Health Aging. 2017;16(5):1-7.

12. Cerin E, Sit CHP, Zhang CJP, Barnet A, Cheung MMC, Lai P, et al. Neighbourhood environment, physical activity, quality of life and depressive symptoms in Hong Kong older adults: a protocol for an observational study. BMJ Open. 2016;6(1):1-17.

13. Marques LP, Shineider IJC, Ursos E. Quality of life and its association with work, the Internet, participation in groups and physical activity among the elderly from the EpiFloripa survey, Florianópolis, Santa Catarina State, Brazil. Cad Saúde Pública. 2016;32(12):1-11.

14. Aguero SM, Leiva AV. Caracterización antropométrica, calidad y estilos de vida del anciano chileno octogenário. Nutr Hosp. 2015;31(6):2554-60.

15. Meneguci J, Sasaki JE, Santos A, Scatena LM, Damião R. Sitting time and quality of life in older adults: a population-based study. J Phys Act Health. 2015;12(11):1513-9.

16. Atkins J, Naismith SL, Luscombe JM, Hickie IB. Psychological distress and quality of life in older persons: relative contributions of fixed and modifiable risk factors. BMC Psychiatry. 2013;13:1-18.

17. Milla PG, Johns PC, Aguero SD. Asociación del consumo de desayuno y la calidad de vida en adultos mayores autonomos chilenos. Nutr Hosp. 2014;30(4):845-50.
18. Zacaroza-Martí A, Ferrer-Cascalez R, HurtadoSánchez JA, Laguna Pérez A, Carboñero-Matínez MJ. relationship between adherence to the mediterranean diet and health-related quality of life and life satisfaction among older adults. J Nutr Health Aging. 2018;22(1):89-96.

19. Bayán-Bravo A, Péres-Tasigchana RF, Sayón-Orea C, Matínez-Gomez D, López-Garcia E, RodríguezArtalejo F, et al. Combined impact of traditional and non-traditional healthy behaviors on health-related quality of life: a prospective study in older adults. Plos ONE. 2017;12(10):1-10.

20. Machón M, Larrañaga I, Dorronsoro M, Vrotsou K, Vergara I. Health-related quality of life and associated factors in functionally independent older people. BMC Geriatr. 2017;17(19):1-9.

21. Gouveia ERQ, Gouveia BR, Ihle A, Kliegel M, Maia JA, Badia SBI, et al. Correlates of health-related quality of life in young-old and old-old communitydwelling older adults. Qual Life Res. 2017;26(6):1561-9.

22. Moreno-vecino B, Arija-Blázquez A, PedreroChamizo R, Gómez-Cabello A, Alegre LM, Pérez-Lopez FR, et al. Sleep disturbance, obesity, physical fitness and quality of life in older women: EXERNET study group. Climacteric. 2017;20(1):72-9.

23. Camelo LV, Giatti L, Barreto SM. Qualidade de vida relacionada à saúde em idosos residentes em região de alta vulnerabilidade para saúde de Belo Horizonte, Minas Gerais. Rev Bras Epidemiol. 2016;19(2):280-93.

24. Dohrn I, Hagströmer M, Hellénius M, Ståhle A. Gait speed, quality of life, and sedentary time are associated with steps per day in community-dwelling older adults with osteoporosis. J Aging Phys Act. 2016;24(1):22-31.

25. Blair CK, Robien K, Inoue-Choi M, Rahn W, Lazovich D. Physical inactivity and risk of poor quality of life among elderly cancer survivors compared to women without cancer: the Iowa Women's Health Study. J Cancer Surv. 2016;10(1):103-12.

26. Harada K, Shibata A, Oka K, Nakamura Y. Association of muscle-strengthening activity with knee and low back pain, falls, and health-related quality of life among japanese older adults:a crosssectional survey. J Aging Phys Act. 2015;23:1-8.

27. Duran S, Mattar P, Bravo N, Moreno C, Reyes S. Asociación entre calidad de vida y cantidad de sueño en adultos mayores de la Región Metropolitana y Región de Valparaíso, Chile. Rev Med Chile. 2014;142:1371-6.

28. Freitas CS, Meereis ECW, Gonçalves MP. Qualidade de vida de idosos ativos e insuficientemente ativos do município de Santa Maria (RS). Rev Kairós. 2014;17(1):57-68. 
29. Silva MF, Goulart MBA, Lanferdini FJ, Marcon M, Dias CP. Relação entre os níveis de atividade física e qualidade de vida de idosos sedentários e fisicamente ativos. Rev Bras Geriatr Gerontol. 2012;15(4):635-42.

30. Footit J, Anderson D. Associations between perception of wellness and health-related quality of life, comorbidities, modifiable lifestyle factors and demographics in older Australians. Aust J Ageing. 2012;31(1):22-7.

31. Guedes DP, Hattman AC, Martini FAN, Borges MB, Bernadelli R. Quality of life and physical activity in a sample of brazilian older adults. J Aging Health. 2012;24(2):212-26.

32. Porto DB, Guedes DP, Fernandes RA, Reichert FF. Perceived quality of life and physical activity in Brazilian older adults. Motricidade. 2012;8(1):33-41.

33. Instituto Brasileiro de Geografia e Estatística. Mudanças Demográficas no Brasil no Século XXI. Rio de Janeiro: IBGE;2015. (Informações demográficas e socioeconômicas, $\mathrm{n}^{\mathrm{o}} 3$ )

34. Andrade JMO, Rios LR, Teixeira LS, Vieira FS, Mendes DC, Vieira MA, et al. Influência de fatores socioeconômicos na qualidade de vida de idosos hipertensos. Ciênc Saúde Colet. 2014;19(8):3497-3504.

35. Añez CRR, Reis RS, Petroski EL. Versão brasileira do questionário “Estilo de Vida Fantástico”: tradução e validação para adultos jovens. Arq Bras Cardiol 2008;91(2):102-9.

36. Belloc NB, Breslow L. Relationship of physical health status and health practices. Prev Med. 1972:409-21.

37. Nahas MV, Barros MGV, Francalacci V. O Pentáculo do bem-estar: base conceitual para a avaliação do estilo de vida de indivíduos e grupos. Rev Bras Ativ Fís Saúde. 2000;5(2):48-59.

38. Goulart D, Goulart P, Ely LS, Sgnaolin V, Santos EF, Terra NL, et al. Tabagismo em idosos. Rev Bras Geriatr Gerontol. 2010;13(2):313-20.
39. Martins A, Parente J, Araújo J, Menezes MJ. Prevalência do consumo de risco de álcool no idoso: estudo numa unidade dos cuidados primários da região de Braga. Rev Port Med Geral Fam. 2016;32(4):270-4.

40. Pimenta FB, Pinho L, Silveira MF, Botelho ACC. Fatores associados a doenças crônicas em idosos atendidos pela Estratégia de Saúde da Família. Ciênc Saúde Colet. 2015;20(8):2489-98.

41. Teixeira SM, Rodrigues VS. Modelos de família entre idosos: famílias restritas ou extensas? Rev Bras Geriatr Gerontol. 2009;12(2):239-54.

42. Benedetti TRB, Antunes PC, Rodrigues-Añez R, Mazo GZ, Petroski EL. Reprodutibilidade e validade do Questionário Internacional de Atividade Física (IPAQ) em homens idosos. Rev Bras Med Esporte. 2007;13(1):11-5.

43. Kopiler DA. Atividade física na terceira idade. Rev Bras Med Esporte. 1992;3(4):108-11.

44. Machado RSP, Coelho MASC, Coelho KSC. Percentual de gordura corporal em idosos: comparação entre os métodos de estimativa pela área adiposa do braço, pela dobra cutânea tricipital e por bioimpedância tetrapolar. Rev Bras Geriatr Gerontol. 2010;13(1):17-27.

45. Rech CR, Petroski EL, Boing O, Babel Junior EJ, Soares MR. Concordância entre as medidas de peso e estatura mensuradas e auto-referidas para o diagnóstico do estado nutricional de idosos residentes no Sul do Brasil. Rev Bras Med Esporte. 2008;14(2):126-31.

46. Felix LN, de Souza EMT. Avaliação nutricional de idosos em uma instituição por diferentes instrumentos. Rev. Nutr. 2009;22(4):571-80.

47. Woodside JV, Galagher NE, Neville CE, McKinley MC. Mediterranean diet interventions to prevent cognitive decline: portunities and challenges. Eur J Clinic Nutr. 2014;68:1241-4. 